\title{
Cyclic adenosine monophosphate : Recent and future perspectives on various diseases
}

\author{
Amol P. Muthal ${ }^{*}$ (D), Ravindra Kulkarni², Dileep Kumar², Chandrakant Bagul², Anwesha A. Mukherjee-Kandhare ${ }^{1}$, Amit D. \\ Kandhare ${ }^{1}$, Shirish D. Ambavade ${ }^{3}$, Vaibhav Wagh ${ }^{4}$, Subhash L. Bodhankar ${ }^{1}$ \\ ${ }^{1}$ Department of Pharmacology, Poona College of Pharmacy, Bharati Vidyapeeth Deemed University, Pune, India. \\ ${ }^{2}$ Department of Pharmaceutical Chemistry, Poona College of Pharmacy, Bharati Vidyapeeth Deemed University, Pune, India. \\ ${ }^{3}$ School of Pharmaceutical Sciences, Sanjay Ghodawat University Kolhapur, India. \\ ${ }^{4}$ Pharmaceutical Chemistry Department, N. N. Sattha college of Pharmacy, Ahmednagar, India.
}

\section{ARTICLE INFO \\ Received on: $13 / 07 / 2021$ \\ Accepted on: 22/09/2021 \\ Available Online: 05/03/2022}

\section{Key words:}

Second messenger, cAMP, drug-cAMP interaction, cancer.

\begin{abstract}
A large number of messengers of ion and small molecules distribute cell receptor signals into the protein effector. As a second cardinal messenger, adenosine 3', 5'-cyclic monophosphate (cAMP) is a nucleotide active in a multitude of signal pathways. The other messengers have greater involvement in the drug receptors or receptor-ligand, decreased protein activation, and less neural pathway regulation. cAMP is a promising second messenger because it controls the activity of various proteins and enzymes and makes it a second effective messenger with greater concentration in most body tissues. Local cAMP signals have become recognized worldwide in four major diseases: cancer, cataracts, diabetes, and cardiovascular diseases. Therefore, cAMP's current status and statics relative to its characteristics were here attempted, involving simple synthesis in different directions. A few additional cAMP-play positions are now known as the second messenger and new finders in this field and experiences with cAMP and medicaments such as salmeterol, theophylline, metoprolol, desmopressin, morphine, and ranitidine. In conjunction with the recent developments described in these studies, cAMP patents provide a clear overview of cAMP's future business interest and require more ingenuity within the organization to transmit communications and signals through other emerging technologies, such as artificial intelligence.
\end{abstract}

\section{INTRODUCTION}

In some cases, signals transduced inside the cell-bycell surface receptors are often transmitted by the generation of minute molecules called second messenger molecules that quickly scatter (Fig. 1). When a ligand is bonded to a specific receptor, it changes the receiver's protein content to activate proteins that catalyze the second ion messenger's production or release or inflow (Das, 2004; Dennis et al., 1991; Hongjun, 2017; Lee et al., 2017; Newton et al., 2016). Most of the second messengers are small and thus easily distributed from a cytoplasm that allows

\footnotetext{
*Corresponding Author

Amol P. Muthal, Department of Pharmacology, Poona College of Pharmacy, Bharati Vidyapeeth Deemed University, Pune, India.

E-mail: shrirampmuthal@gmail.com
}

information to transmit instantly across the cell and be classified as cyclical. A few cell types are established by the second and guanosine 3', 5' cyclic monophosphate (cGMP) transmitter (Ab Naafs, 2017; Lee, 2015).

Given the importance of this intracellular signal, adenosine 3',5' cyclic monophosphate (cAMP) levels in cells are not unexpectedly regulated by certain forms of phosphodiesterases (PDE), and cAMPenhancement activates protein kinases (PK) (Jing et al., 2021; Lee, 2015). cAMP is a particular second messenger for several genes in a nervous system (Hoeffler et al., 1988). The cAMP is also recognized as a strong adverse receptor in T cells, decreasing T cells' defenses, but the cAMP/protein tyrosine kinase (PK) A indicates the pathway. A potentially important regulator is the lymphocyte PTK factor (Vang et al., 2001). cAMP can be produced in mammalian cells by the action of adenylyl cyclase (AC), soluble ACs, and transmembrane ACs, allowing the two 
enzyme family members to satisfy such physiological purposes (Danchin, 1993; SIA, 2018). Improved cAMP production controls the activity and channel of the enzyme in eukaryotic cells, mainly by using PK dependent on cAMP (Houslay, 1997; Takagi et al., 2019). The main and most powerful signal channels in eukaryotic cells are cAMP/PKA and anchoring proteins (AKAPs), targeted at substrates and distinct subcellular compartments (Brudvik et al., 2011). Catalytic binding of adenosine triphosphate (ATP) to the metabotropic receptors activated a cascade inside the cell. cAMP offers to guide in particular substrates and subcellular separated components for glycogen, sugar, lipid, and AKAPs, which offer spatial and temporary flexibility for mediation of biological effects of the cAMP/PKA channel (Brudvik et al., 2011; Loomans et al.,
2018). The adherence and release of enzymes, such as G-proteins, is from ATP, if triggered; cAMP monitors glycogen, insulin, and fat synthesis (Prasad, 1980).

cAMP-dedicated signaling pathways for the bone sialoprotein gene and regulating medium active osteocalcin under androgen-repressed human prostatic cancer cell line conditions have a higher significance in human prostate cancer (Huang et al., 2005; Strømland et al., 2016). cAMP and cGMP have an incredibly complicated function in reporting, tracking, and determining their downstream effectors, including PKA and PKG. cAMP and cGMP aid or damage cell growth and cell or tissue defense (Fajardo et al., 2014; Kong, 2017). Four diseases connected to cAMP are back

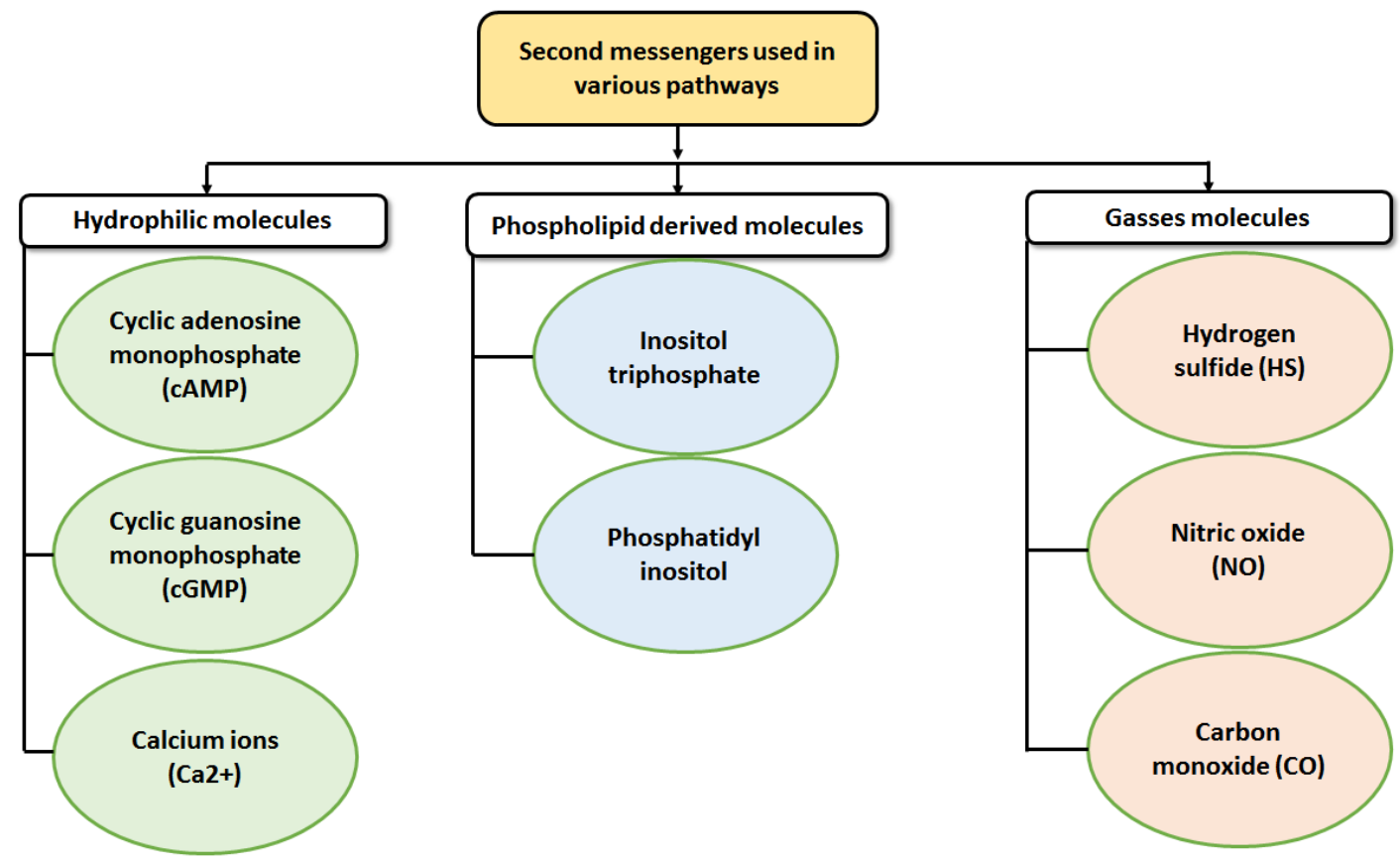

Figure 1. Second messengers used in various pathways.

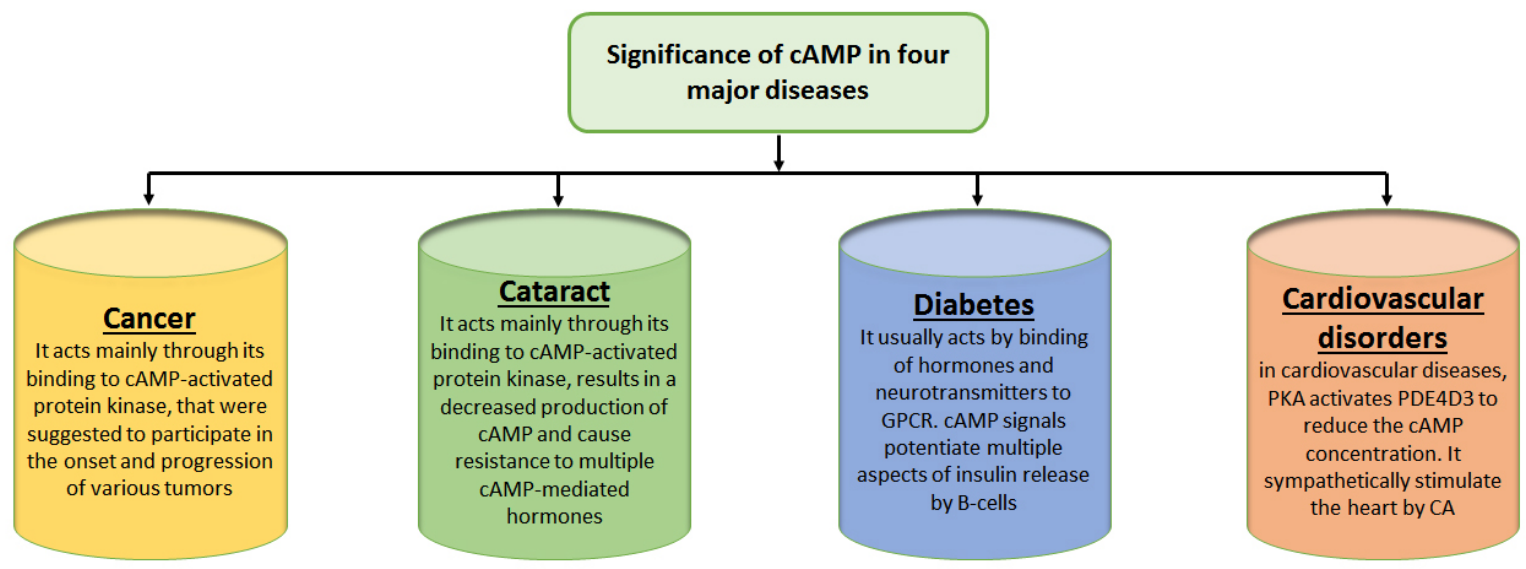

Figure 2. Significance of cAMP in four major diseases. cAMP: Adenosine 3',5' cyclic monophosphate; GPCR: G-protein-coupled receptor; PDE: Phosphodiesterase; PKA: Protein kinase A. 
disease, cataract, diabetes, and coronary cardiac disease (Gold et al., 2013) (Fig. 2).

\section{Second messengers}

Second messengers are cellular biomolecules that transmit messages from a source to a destination and have been coined upon discovery to characterize hormone materials and other molecules that act as "first messengers" of biological information transmission outside the cells (Sutherland and Rall, 2002). Gas stimulates adenyl loops, increases cytosolic cAMP concentration, inhibits adenyl cyclases due to tonic PDE action, and decreases cAMP concentration (Clarke et al., 2017; Gerfen and Bolam, 2010). The second message indicates intracellular signaling pathways that increase the signal, leading to activated or inhibited transcription factors, leading to cell reaction (González-Espinosa and Guzmán-Mejía, 2014; Zhang et al., 2019). Extracellular second messengers are released during the transduction phase after the first transmitter, such as a hormone or neurotransmitterdependent receptor activation (Prasad, 1980) (Fig. 3).

\section{Characteristic features of a second messenger system}

The second signaling framework includes many functions such as drug-receptor, receptor-ligand interactions, local intervention, and distal diffusion to relay signals and summarizes fundamental characteristics:

The receptor-ligand or drug-receptor interaction frequently fails to activate the intracellular effectors precisely.

A reference molecule is also used as an alternate signal.

The target molecule is synthesized or released for receptor-ligand interaction and ultimately degraded.
This molecule has a closely regulated synthesis and degradation process to regulate the degree of receptor reaction and can be used to induce or avoid a reaction.

The second messenger molecule can scatter or act locally to transfer the signal to different targets. Several second messenger mechanisms may interact to produce complex responses to the binding receiver line (McKnight, 1991; Newton et al., 2016).

\section{Road to warn second messengers}

Second phosphoinositol messengers showed herein and the phosphoinositol-derived messengers are inositol-1,4,5triphosphate (IP3), diacylglycerol (DAG), and $\mathrm{Ca}^{2+}$. The path starts with their receptors, including angiotensin, gonadotropinreleasing hormone, growth hormone-releasing hormone, oxytocin, and thyrotropin-releasing hormone, as major extracellular messengers. Epinephrine is associated with G-protein-coupled receptor (GPCR) alpha1, M1, and M2 acetylcholine receptors (Graham et al., 1996; Xue et al., 2019). Exposure to such receptors by the primary messenger can lead to conformational changes in the receptor. The $\alpha$-subunit releases guanosine diphosphate (GDP) and attaches guanosine triphosphate (GTP) through guanine nucleotide exchange factors (GEF), contributing to subunit isolation and corresponding behaviors (Wedegaertner et al., 1995). The generation of secondary phospholipase C (PLC) and IP3 (Hughes and Putney, 1990), phosphatidylinositol-4, and 5-bisphosphate is prevented by the active subunit (IP2). IP3 binds $\mathrm{Ca}^{2+}$ to the endoplasmic reticule of the calcium pump, a second conduit (Li et al., 2020; Yoshida and Imai, 1997). Ultimately, $\mathrm{Ca}^{2+}$ binds to a large number of enzymes, initiating an enzyme cascade (Fig. 4).

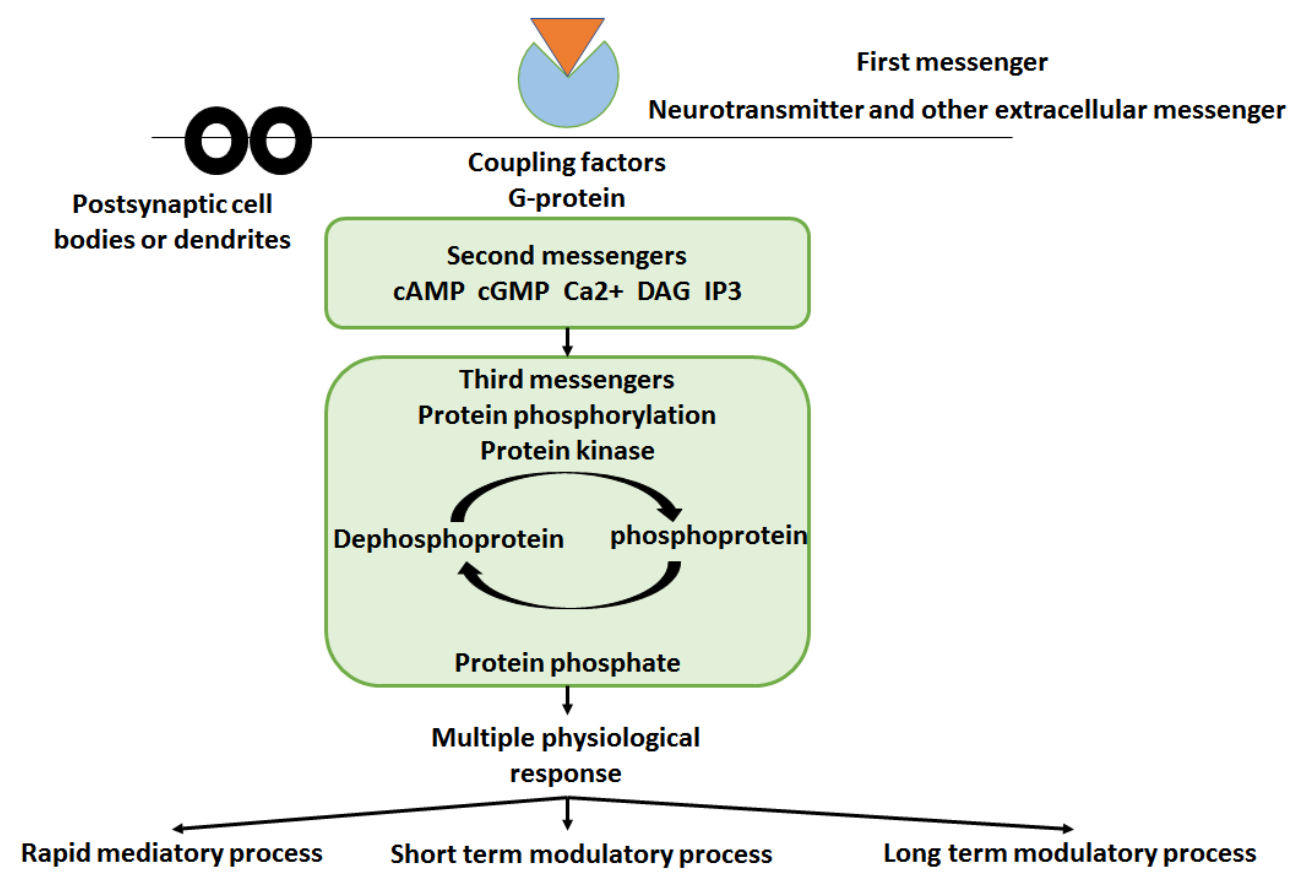

Figure 3. General mechanism of second messengers.

cAMP: Adenosine 3',5' cyclic monophosphate; cGMP: Guanosine 3',5' cyclic monophosphate; DAG: Diacylglycerol; IP3: inositol-1,4,5-triphosphate. 


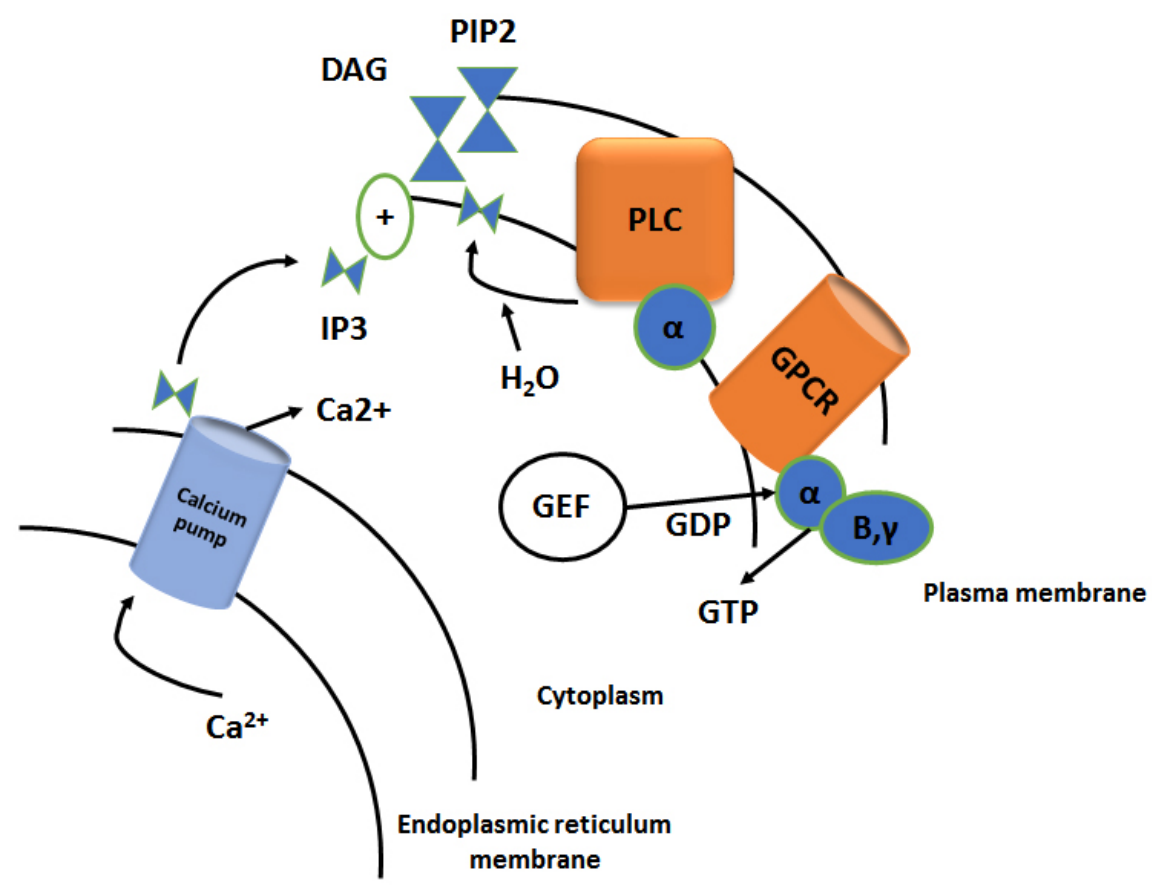

Figure 4. Signaling pathway of second messengers.

DAG: Diacylglycerol; GDP: Guanosine diphosphate; GEF: Guanine nucleotide exchange factors; GPCR: G-protein-coupled receptor; GTP: Guanosine triphosphate; IP3: inositol-1,4,5-triphosphate; PIP2: Phosphatidylinositol 4, 5-bisphosphate; PLC: Phospholipase C.

\section{Grouping of second messengers}

Second messengers are molecules that relay signals received to target cytosol and nucleus molecules at cell surface receptors, such as growth factors, protein hormones, etc. In the nervous system, there are some significant second messengers.

The four major classes of second messengers in the nervous system are as follows:

Cyclic nucleotides - cAMP and cGMP;

Hydrophobic molecules - $\mathrm{IP}_{3}$ and DAG;

Hydrophilic molecules $-\mathrm{Ca}^{2+}$;

Gaseous second messenger - NO and CO.

\section{Cyclic nucleotides}

Second messengers could be grouped into four different categories, viz. cyclic nucleotides, exemplified by cAMP and other soluble molecules located within cytosol; the second type involves lipid messengers that signal within cell membranes; the third category of second messengers are ions that signal within and between cellular compartments; and lastly, the gases and free radicals type of second messengers are involved in transducing intercellular and intracellular signals. cAMP is synthesized with G-protein and receptor downstream adenylate cyclase enzymes and PDE regulates cGMP (Cooper, 1982).

cAMP: In general, cAMP, the first intracellular second ligand transporter to be identified in 1957, is accepted in all living organisms as an essential gene expression and metabolism regulator (Beavo and Brunton, 2002; Xu et al., 2020). cAMP controls proand anti-inflammatory activities in the immune system: drugs that increase the level of intracellular cAMP, increase the level of antiinflammatory factors, and decrease the output of pro-inflammatory mediators in different immune cells (Liang, 2017a; Raker et al., 2016b). AC enzymes, heterotrimeric G-proteins (guanine nuclear protein), and downstream receptors are used to synthesize cAMP. For instance, activation of G-proteins stimulates the synthesis of AC cAMP when epinephrine is linked to $\beta$-adrenergic receptors in cell membranes (Friebe et al., 2020).

cGMP: cGMP is an essential intracellular $\mathrm{Ca}^{2+}$ regulator and regulates physiological functions dependent on $\mathrm{Ca}^{2+}$ in smooth muscle, pituitary, retinal, and other cells. The metabolism or activity of normal rod-dominant retinas tends to be involved in cGMP. An excess in cGMP levels contributes to photoreceptor death and blindness in degenerative disorders. Therefore, cGMP is an essential modulator of rod photoreceptors, probably a visual transduction component (Friebe et al., 2020).

Regulation pathway of cGMP: PDEs closely regulate the cGMP pool in the cell, precisely split into the cyclic phosphate molecule of cAMP 3', 5", and cGMP to match the 5" nucleotide (Kukreja et al., 2012). By activating the soluble peptide solution, cGMP regulatory bypasses such as postconditioning, preconditioning, nitric oxide (NO) donors, cinaciguat, and atrial naturiuretic peptide (Kukreja et al., 2012) generate cGMP PKG and induce extracellular signal-regulated kinase (ERK)1/2 and phosphorylated glycogen synthase kinase phosphorylation. PKG also opens mitochondrial-sensitive $\mathrm{K}$ channels that minimize the risk of ischemic/reperfusion injury by maintaining ATP and $\mathrm{Ca}^{2+}$ influx in mitochondria (Kukreja, 2012) (Fig. 5).

\section{Hydrophobic molecules}

Hydrophobic molecules such as DAG, inositol phosphate signaling molecule (Insp3), and phosphatidylinositol 


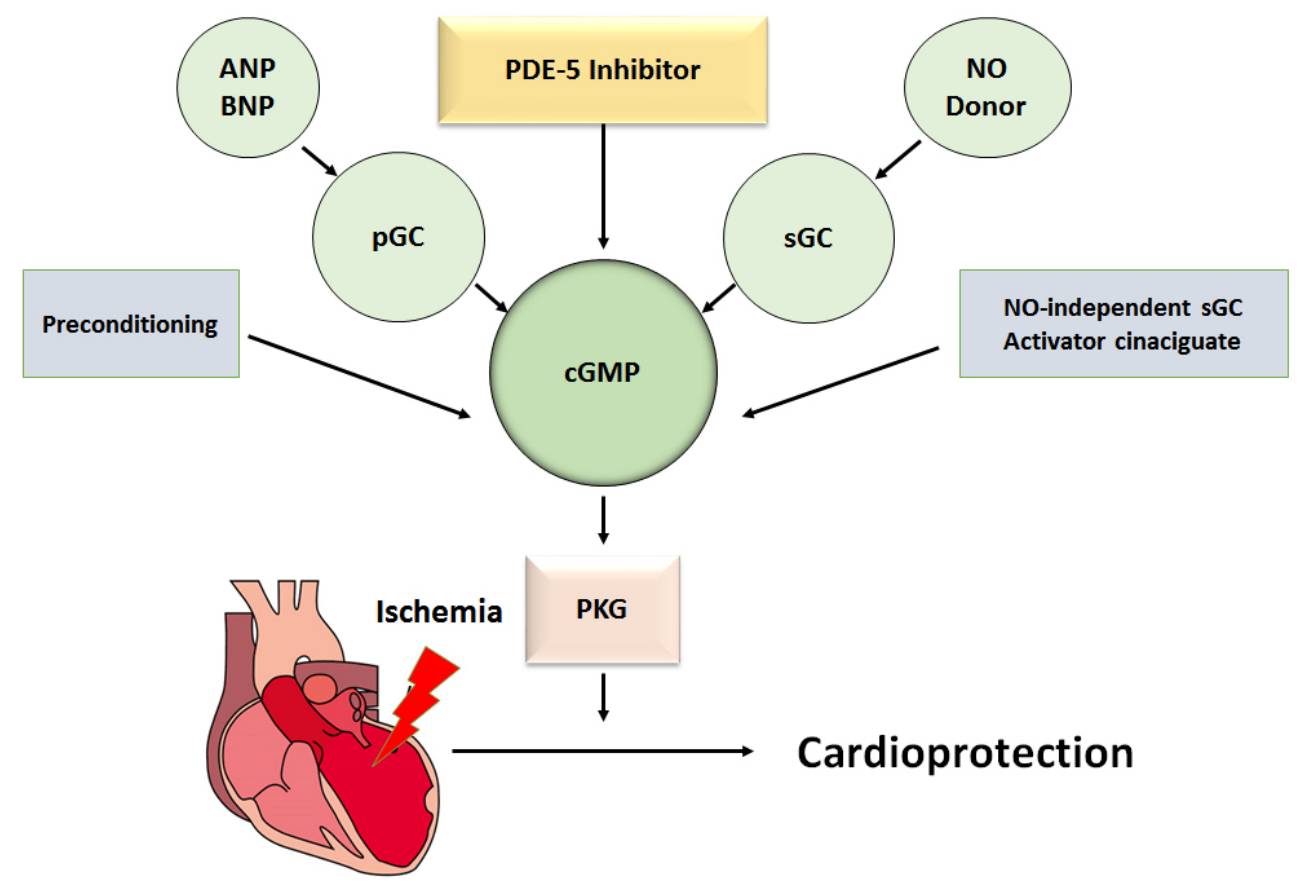

Figure 5. Regulation of cGMP by PDEs.

ANP: Atrial natriuretic peptides; BNP: B-Type natriuretic peptide; cGMP: Cyclic guanosine monophosphate; NO: Nitric oxide; PDE: Phosphodiesterases; pGC: Particulate guanylyl cyclases; PKG: Protein kinase G; sGC: Soluble guanylyl cyclases.

are membrane-associated and migrate from the plasma membrane into the juxtamembrane space where membrane-associated effector proteins can be reached and controlled.

DAG and IP3: Sn-1, 2-diacyl glycerol lipophilic second messenger (DAG) is produced in vivo from membrane phosphatidylinositol 4, 5-bisphosphate (PIP2) by PLC response to the induction of different G-protein-coupling receptors and tyrosine kinases. Both GPCR (e.g., histamine receptors) and receptor tyrosine kinase (RTK, e.g., epidermal growth factor receptor signals) can result from PLC activation, which splits phospholipids into DAG and IP3 (Tsui and York, 2010). A tiny, globally recognized domain $\mathrm{C} 1$ in PKC is the DAG sensor. Around 30 other $\mathrm{C} 1$ proteins including D-Ras, polypeptides for gastrin release, DAG kinase, and n-chimaerininase (Colon-Gonzalez and Kazanietz, 2006). G-protein-receptor endothelial-dependent vasodilatation that activates second transporter cascades is carried out by related receptor-dependent agonists such as ATP, thrombin, dopamine, histamine, and bradykinin. PLC $\mu$ activation thus induces IP3 and DAG secondary lipid messengers that increase intracellular $\mathrm{Ca}^{2+}$ to emit $\mathrm{NO}$, calming agents synthesized by endothelia (Prokazova et al., 2007). The relaxing factor NO is generated by this activation.

Regulation pathway of DAG and IP3: Higher $\mathrm{Ca}^{2+}$ intracellular levels often trigger IP3 activation. In the PLC- $\beta$ isozyme, the alpha subunit $\mathrm{Gq}$ binds and induces activation, leading to the separation of PIP2 from IP3 and DAG (Katzung and Katzung, 2018) when the ligand is connected to a GPCR. The PLC $-\mu$ receptor has tyrosine residue that can be phosphorylated by stimulation of RTK. On the contrary, PLC-ć is inhibited by the RTK receptor causing the split of PIP2 into DAG and IP3. This is the case in cells that may react to growth factors such as insulin, as growth factors are ligands that trigger RTK. IP3 is a soluble agent that can spread endoplasmic reticulum (ER) to muscle cells via cytoplasm or sarcoplasm reticulum due to its action. In the ER, IP3 binds to the IP3 receptor in a ligand-gated $\mathrm{Ca}^{2+}$ channel on the ER surface. The relationship of IP3 (the ligand in this instance) to the IP3 receptor allows the $\mathrm{Ca}^{2+}$ channel to open and thus release $\mathrm{Ca}^{2+}$ into a cytoplasm (Barrett et al., 2010). The sarcoplasmic reticulum receptor channel is helped by this increase in $\mathrm{Ca}^{2+}$ in cardiovascular cells to further boost the release of $\mathrm{Ca}^{2+}$ through calcium release. IP3 can also indirectly activate $\mathrm{Ca}^{2+}$ channels on the cell membrane by increasing intracellular $\mathrm{Ca}^{2+}$ concentrations (Rhee, 2001) (Fig. 6).

\section{Hydrophilic molecules}

Calcium ions $\left(\mathrm{Ca}^{2+}\right)$ : Calcium is an extremely flexible intracellular messenger that controls several target proteins' behavior by controlling a wide variety of cellular functions. Calcium cell-related effects can be controlled by directly binding a target protein or calcium stimulus receptor that increases calcium level and then triggers specific downstream responses (Newton et al., 2016). The most common signal transduction factor in the cells of bacteria-to-specialized neurons is $\mathrm{Ca}^{2+}$, which is essential for life. As in many other secondary messenger molecules, sustained high intracellular $\mathrm{Ca}^{2+}$ rates contribute to cell death. Like other second messenger molecules, several binding and unique extraction proteins cannot metabolize $\mathrm{Ca}^{2+}$, meaning that cells regulate intracellular levels tightly (Clapham, 1995).

Regulation pathway of $\mathrm{Ca}^{2+}$ : Cytoplasmic $\mathrm{Ca}^{2+}$ content is generally maintained at approximately $100 \mathrm{nM}$, i.e., 20,000- 


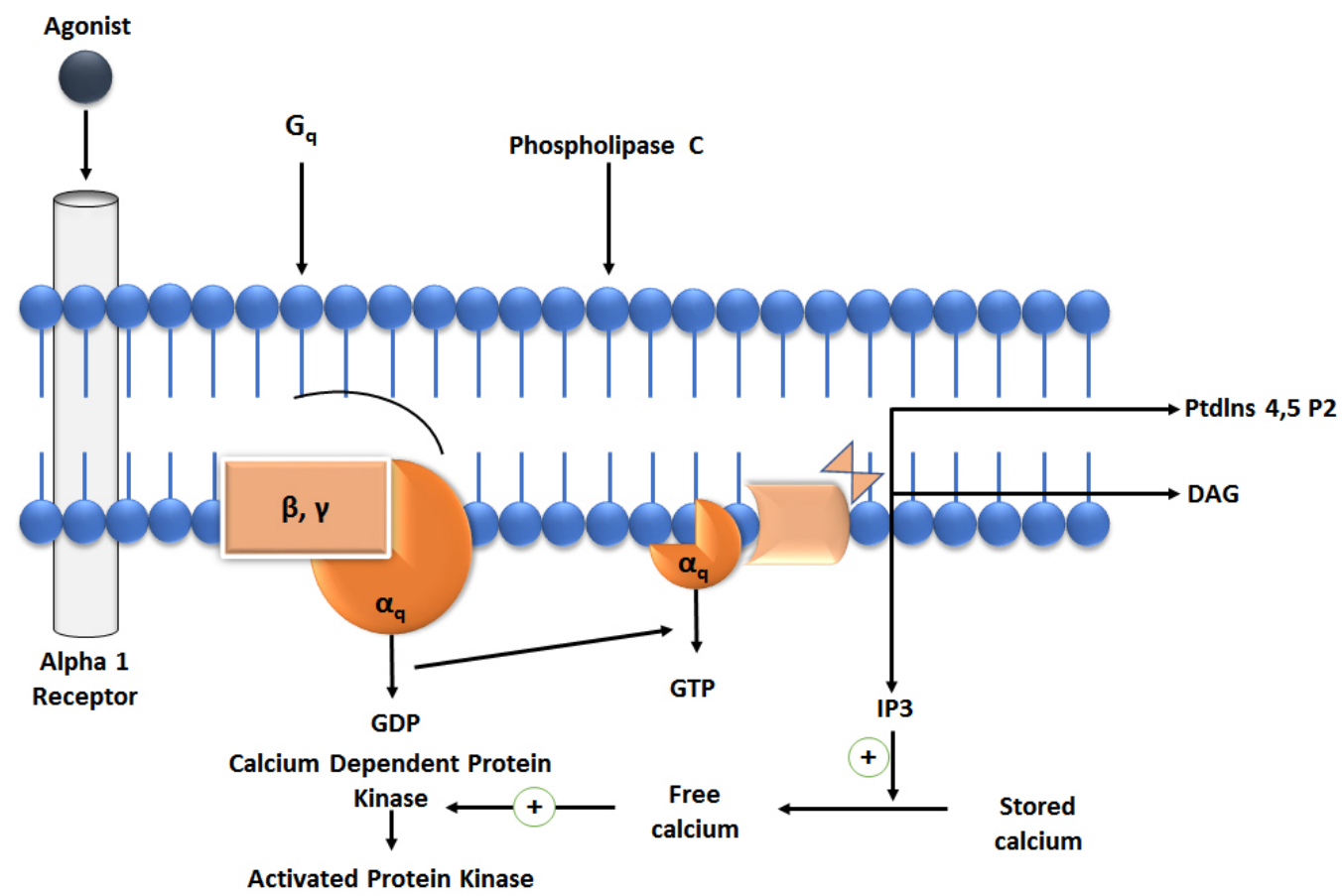

Figure 6. Signaling pathway of DAG and IP3.

DAG: Diacylglycerol; GDP: Guanosine diphosphate; GTP: Guanosine triphosphate; IP3: Inositol triphosphate; Ptdlns 4,5 P2: Phosphatidylinositol biphosphate.

100,000 times higher than the normal extracellular concentration. $\mathrm{Ca}^{2+}$ is continuously transported to extracellular space to maintain this low concentration, cytosol ER, and mitochondria. Signaling occurs if the cell can expel $\mathrm{Ca}^{2+}$ ions from the intracellular supply and if $\mathrm{Ca}^{2+}$ leaves the cell via the ion channels of the plasma membrane (Parys and De Smedt, 2012). The most powerful signaling pathway for increasing cytoplasmic calcium concentration is PLC (Fig. 7).

Many cell-surface receptors activate the enzyme PLC, including G-binding and tyrosine kinases.

In two traditional second messengers, IP3 and DAG, PLC hydrolyzes the PIP2 membrane's phospholipid.

DAG uses plasma membrane PKC.

IP3 diffuses and binds to IP3 ER.

As a $\mathrm{Ca}^{2+}$ sequence, the IP3 receiver eliminates $\mathrm{Ca}^{2+}$ from the ER.

Binding $\mathrm{Ca}^{2+}$ PKC ions activates it (Alberts et al., 2013).

Gaseous second messenger

Novel intercellular messengers are gaseous second messengers. The detection of two gaseous transporter compounds was an exceptional finding in neurotransmitter pathway research. NO is the first and carbon monoxide (CO) is the other (Meyer, 1997).

Nitric oxide (NO): NO is a free radical gas that plays a major role in at least three physiological systems as a gaseous messenger molecule: white blood cells where NO mediates tumor and bactericidal effects; blood vessels where endothelial relaxing factor activity is now known to be similar; and most recently as a neuronal portion with functions corresponding to endothelial relaxing factor activity (Broillet and Firestein, 1996).
Carbon monoxide (CO): NO may not be the only tiny gas molecule that works as a potential brain messenger and a neurotransmitter. $\mathrm{CO}$, like $\mathrm{NO}$, can interact with heme groups to generate cGMP. Isocytes of heme oxygenase are also shown to be located in comparison with a relationship calculated in different preparations between the development of heme oxygenase, $\mathrm{CO}$ rates, and cGMP (Leinders-Zufall et al., 1995). While CO and NO show some functional similarities in their ability to generate cGMP, there are distinct functions indicated by significant variations. Specific NO and CO enzymes are distributed by the nervous system (Verma et al., 1993). Various signaling mechanisms for location, cGMP, DAG, IP3, $\mathrm{Ca}^{2+}$, and NO are shown in Table 1.

\section{Roles of second messengers}

Several forms of second messengers exist. We have numerous positions given below as possible second messengers.

The cAMP transporter mediates some short-term synaptic transmission elements: any rapid action of some neurotransmitters on ion channels not affecting ligand-gated channels is regulated by cAMP.

The second receptor, cGMP, mediates a wide range of physiological processes, from ion channel conductance to cell growth and apoptosis to cell proliferation and contractility (Tsai and Kass, 2009).

The second messenger DAG specifically inhibits protein $\mathrm{C}$ and regulates various proteins' phosphorylation in the intracellular system.

Calcium is essentially eliminated from intracellular sources by another second IP3 messenger. $\mathrm{Ca}^{2+}$ regulates the function of various enzymes, contractile proteins, and ion channels. 


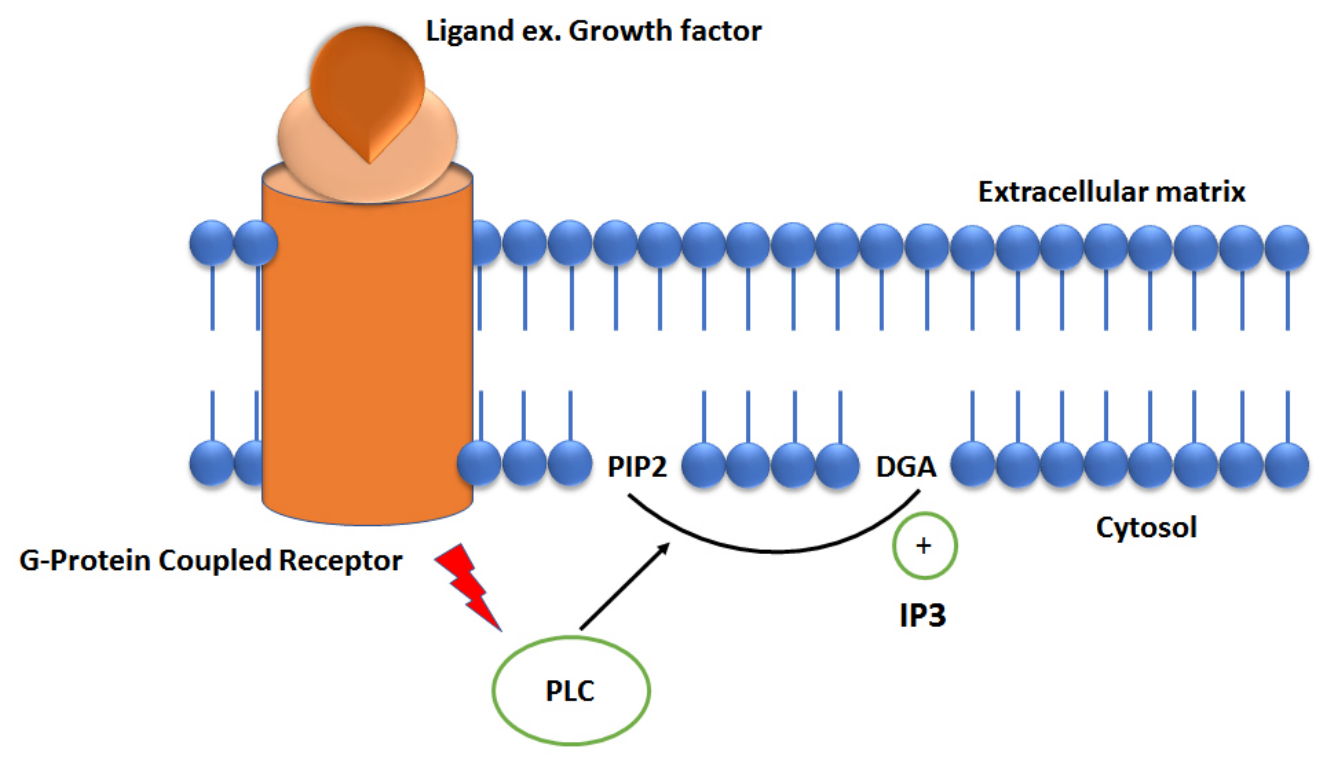

Figure 7. Signaling pathway of calcium concentration $\left(\mathrm{Ca}^{2+}\right)$.

DAG: Diacylglycerol; IP3: Inositol triphosphate; PIP2: Phosphatidylinositol-4,5-biphosphate; PLC: Phospholipase C.

Table 1. Specific signal and generation pathway of second messengers.

\begin{tabular}{|c|c|c|}
\hline $\begin{array}{l}\text { Second } \\
\text { messenger }\end{array}$ & Generation pathway & Specific signal \\
\hline \multirow[t]{2}{*}{ cAMP } & $\begin{array}{l}\text { Receptor phosphorylation, ACs, and } \\
\text { PDEs by PKA }\end{array}$ & $\begin{array}{l}\text { Some signaling pathways, such as calcium signaling mechanisms (through calmodulin, CamKII, } \\
\text { CamKIV, and calcineurin), all of the G-protein subunits (e.g., Gi, GG, and Gq proteins), the } \\
\text { inositol lipid (by PKC), and tyrosine kinase (through ERK and PKB) (Fimia and Sassone-Corsi, } \\
\text { 2001) }\end{array}$ \\
\hline & & , regulate ACs and PDEs activation. \\
\hline IP3 and DAG & G-coupled receptor binding or RTKs & The activation contributes to PIP2 induction into IP3, and DAG (Thatcher, 2010). \\
\hline cGMP & $\begin{array}{l}\text { Cyclic nucleotide PDE hydrolysis } \\
\text { of cGMP and signal propagation } \\
\text { termination }\end{array}$ & $\begin{array}{c}\text { cGMP interacts with PKG based on cGMP and kinase G activation (Lincoln and Cornwell, } \\
\text { 1993). }\end{array}$ \\
\hline Calcium ion $\left(\mathrm{Ca}^{2+}\right)$ & $\begin{array}{l}\text { Binding to reservoirs, a tiny volume } \\
\text { attaches to the effectors }\end{array}$ & $\begin{array}{l}\text { Enables different cellular processes that operate over an extended time spectrum leaving the } \\
\text { effectors and buffers and is removed from the cell by different pumps and exchangers (Berridge } \\
\text { et al., 2003). }\end{array}$ \\
\hline NO & $\begin{array}{l}\text { Binding to soluble guanylate cyclase } \\
\text { (sGC) in the target cell }\end{array}$ & The use of NO mimetics such as nitro vasodilators (Greene et al., 2013). \\
\hline
\end{tabular}

The $\mathrm{Ca}^{2+}$ intracellular regulatory protein calmodulin regulates several regulatory activities.

Another important second messenger, G-proteins, reflects the middle management level in the cells' organization and can interact between the receptors and the effector enzymes or ion channels (Liscovitch and Cantley, 1994).

In determining their stimulatory and inhibitory activities in cancer cells, the role of cAMP and cGMP in signaling and activating downstream effectors (i.e., PKA and PKG) is complex (Hughes and Putney, 1990).

Identification of the second messenger actions of cGMP has become easier than cAMP. It presumably represents lower cGMP concentrations in most tissues, and cAMP plays a significant role in cell function (Brady, 2005).
cAMP

Different types of second messengers have been identified in the nervous system above, but the cAMP is crucial and this review focuses on it. Initially, cAMP was identified as a liver glycogen-breakdown regulator and is now recognized as a second messenger for a broad range of animal cellular responses. Its structure is shown in Figure 8 (Assmann, 1995). Many of the effector molecules by which cAMP and cGMP operate, including PK dependent on cAMP and cGMP, cyclic nuclear-gated ion channels, and cGMP-regulated PDEs, have also been sequenced and cloned (McKnight, 1991). However, a cell cannot be directly translated from extracellular chemicals to cAMP (first messengers). Intracellular cAMP concentration modulation reflects changes in the cellular environment and improvements in the cellular 


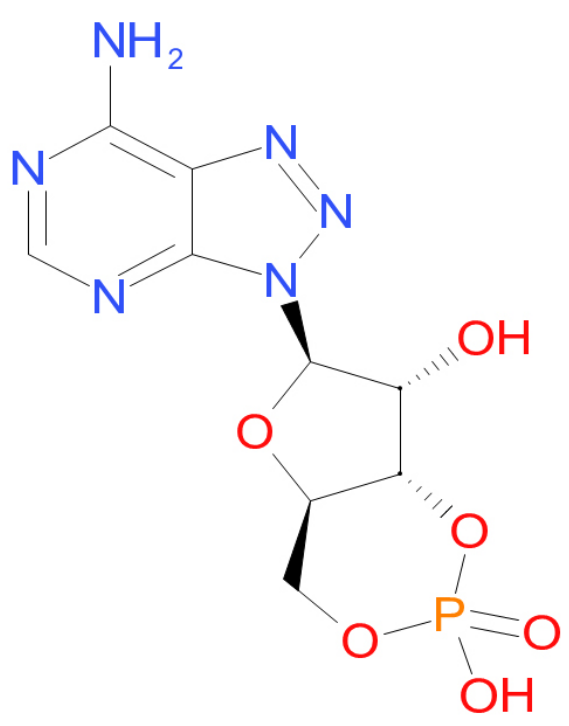

Figure 8. Structure of cAMP.

phase. The cAMP in T cells is the strong negative regulator that dampens $T$ cells' immune function via the cAMP/PKA signaling pathway (Lu et al., 2001). The special function of cAMP signaling is achieved by anchoring proteins with PKA. In T cells, 10-15 unique AKAPs are generated by most cells and 7 AKAPs have been identified to date (Wehbi and Taskén, 2016). PDEs that are discreetly positioned as sinks, which produce multiple cAMP gradients simultaneously in several mobile locations, regulate the spatial and temporal cAMP dynamics (Baillie, 2009).

\section{Synthesis pathway of cAMP}

Ligands such as epinephrine and glucagon stimulate the protein-coupling $(\mathrm{G})$ receptors of heterotrimeric guanine. cAMP is synthesized from ATP by AC and by inactivating PDE, hydrolyzed to AMP (Maurice et al., 2003). Activation of PKA triggers phosphorylation factors for camp-driven genes in cAMP-response element-binding protein (CREB), inducible cAMP early repressor (ICER)/CRE modulator, cAMP-dependent transcription factor (ATF-1), and CBP transcription. PDE4 decreases intracellular cAMP levels and intracellular cAMP counterbalances (Raker et al., 2016a). The catalytic portion of PKA is prevented primarily by translocation into the nucleus and phosphorylated CREB generation (McLean et al., 2009). For most cell types, cAMP controls many types of cellular activities including metabolism, transcription, and growth (McKnight, 1991). This is mainly controlled by PKA, which relies on cAMP. The signal route's activation is related to cell growth and control of differentiation, ion channel conductivity, and gene transcription (Huang et al., 2005) (Fig. 9).

This is used for intracellular information transduction such as the transmission of hormones such as glucagon and adrenaline by cells unable to move through the plasma membrane. It is a glucagon-like hormone reaction system (Limbird, 2012). The cAMP signaling pathway plays a major role in many cellular responses, including cell formation, cell differentiation, cell proliferation, apoptosis, and metabolism (Spina et al., 2013). Cellular and systemic metabolic pathways are greatly affected by cAMP signaling. The following components will focus on cAMP signal inductors, regulators, and effectors in essential metabolic tissues. Food homeostasis processes and metabolic syndrome, a condition of extreme metabolic dysfunction in multi-tissue cAMP disorder, will be viewed (Ravnskjaer et al., 2015).

\section{cAMP binding site}

Specifically, cAMP experiences water-mediated target protein interactions. In the other subunit's c-helix, three water molecules hydrogen-bonded to each cAMP atom, one interacts with Glu81, the phosphate group, and the side-chain amide group of Gln125. The other two hydrogen water molecules bind to the adenine residue atoms N1 and N7 and the side-chain hydroxyl ring of Thr127 and Ser83, respectively (de Wit et al., 1982).

\section{Various roles of cAMP}

Alzheimer's disease: For synaptic plasticity and memory formation, the cAMP pathway has been well established as being necessary. At least, it is partly responsible for learning and memory deficiencies in Alzheimer's disease and inhibits the cAMP/PKA/ CREB pathway. Therefore, in Alzheimer's disease care, methods to improve this pathway have potential (Martínez et al., 1999).

cAMP regulates cell proliferation and cyst formation in autosomal polycystic kidney disease cells: In autosomal dominant polycystic kidney disease (ADPKD), both epithelial cell proliferation and fluid accumulation are responsible for cyst formation. There were additive effects of cAMP and epidermal growth factors on cell growth in ADPKD cells. In ADPKD cells, cAMP has also stimulated cyst enlargement and fluid secretion (Hanaoka and Guggino, 2000).

cAMP pathway as therapeutic target in autoimmune and inflammatory diseases: In the immune system, cAMP regulates pro- and anti-inflammatory processes: drugs that increase intracellular cAMP rates decrease pro-inflammatory mediator production and increase the output of anti-inflammatory factors in several immune cells (Baillie, 2009).

Cardiac disease: cAMP is an omnipresent intracellular second messenger that regulates many physiological and pathological processes, such as cardiac activity and disease, functioning in isolated subcellular microdomains (Sprenger et al., 2015).

Cataracts: The predominant global cause of blindness is the clouding of the eye lens, known as a cataract. This works by linking PKA activated by cAMP, resulting in decreased cAMP production and can induce resistance to several hormones mediated by cAMP (Gold et al., 2013).

Diabetes: It usually functions by binding proteincoupled receptors to hormones and neurotransmitters. cAMP signals potentiate multiple aspects of $\beta$-cell insulin release. After both glucose-like peptide-1 (GLP1, also referred to as ZGLP1) and glucose-dependent insulinotropic polypeptide stimulation and receptor activation, cAMP accumulates in b-cells (Gold et al., 2013).

Peptic ulcer: Due to the combined effects of secretive and antisecretory stimuli on the gastric mucosa, two humoral agents, adenosine cAMP and prostaglandins (PGE), can play a 


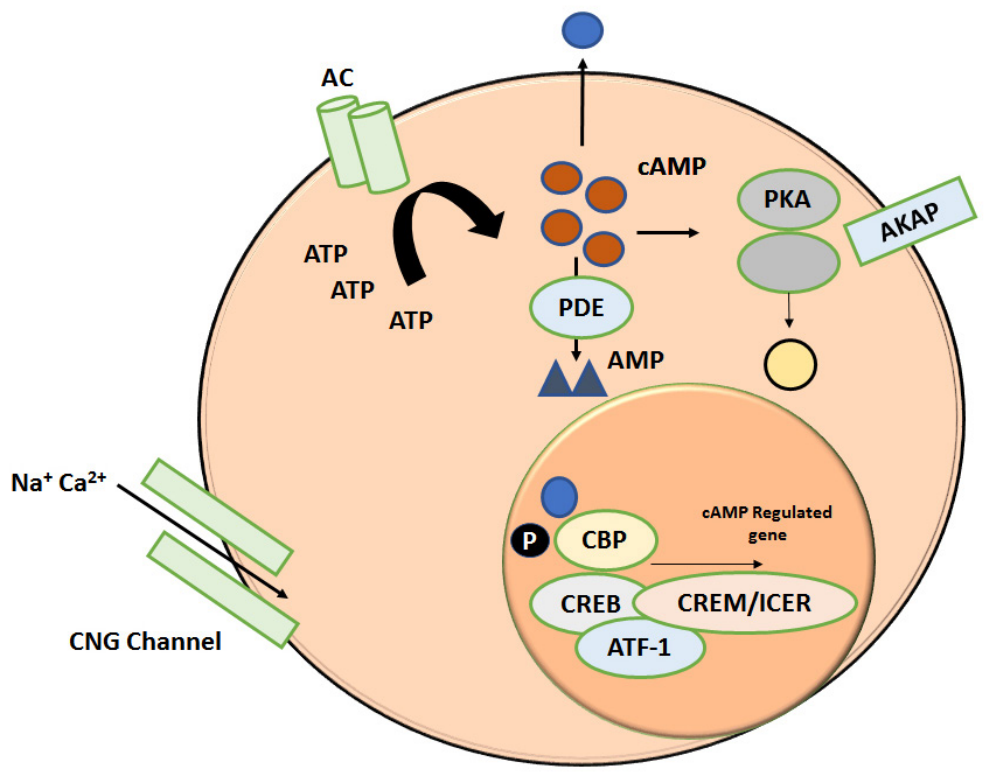

Figure 9. Synthesis pathway of cAMP.

AKAP: Anchoring proteins; ATP: Adenosine triphosphate; ATF-1: Activating transcription Factor-1; CBP: CREB-binding protein; cAMP: Cyclic adenosine monophosphate; CNG: Cyclic nucleotide-gated ion channel; CREB: cAMP response element binding protein; ICER: Inducible cAMP early repressor; PDE: Phosphodiesterase; PKA: Protein kinase A.

major role in the fine adjustment of gastric secretion. cAMP and PGE roles are to regulate gastric secretion through stimulatory and inhibitory stimulation (Dousa and Dozois, 1977).

\section{Role of cAMP apart from the second messenger}

As a therapeutic target in autoimmune and inflammatory disorders, the cAMP pathway.

Molecules of nucleotide signaling help regulate cellular pathways. As a good regulator of innate and adaptive immune cell functions, cAMP is well known. Clinical methods to suppress or enhance cAMP generation or outcomes have the immunoregulatory potential for autoimmune and inflammatory diseases (Baillie, 2009).

The role of cAMP in controlling the metabolism of carbohydrates.

The role of cAMP in regulating the metabolism of carbohydrates is to increase or promote the release of insulin from pancreatic beta cells (Sutherland and Robison, 1969).

The role of cAMP in vascular smooth muscle cells, which are differentiated and trans-differentiated.

In differentiated vascular smooth muscle cells (VSMCs), cAMP's function is to induce relaxation, maintain low levels of proliferation, and maintain contractile morphology and trans-differentiated VSMC by inhibiting proliferation, inhibiting collagen synthesis, inhibiting migration, etc.

cAMP's involvement in hormone activities such as adipose tissue, pancreases, adrenal cortex, corpus luteum, ovary, testis, etc. The purpose of cAMP is to inhibit imidazole-activated methylxanthines, nucleoside triphosphates, pyrophosphate, citrate, and hormone (Butcher et al., 1968).

During the production of dictyostelium, both outside and inside the cell, cAMP plays an important role. Intracellular cAMP has the role of separating stalk and spore cells during dictyostelium development (Reymond et al., 1995).

\section{Detection methods of cAMP}

Some important methods are listed in Table 2 that are useful for detecting changes in cAMP levels.

\section{Third messenger link}

Due to the hormonal activation of GPCRs relative to "stimulatory" G protein (Gs), AC is usually produced by intracellular cAMP. Probenecid and sulfinpyrazone sensitive efflux system, belonging to the ATP binding cassette transport family (Strewler, 1984) will effectively transport the second messenger (Strewler, 1984). It is supposed that neighboring cells with putative (unidentified) receptor proteins are similar to that of extracellular cAMP. Alternatively, sequentially, it is possible to metabolize extracellular cAMP, first with AMP ecto-PDE, then with adenosine ecto-5' nucleotide. Adenosine is used as a paracrine or autocrine messenger by one of the four subtypes of adenosine receptors to activate those signal cascades (A1, A2A, $\mathrm{A} 2 \mathrm{~B}$, and $\mathrm{A} 3$ ). Also, as cAMP is relatively stable in the blood, the circulating cAMP can be converted by ectoenzymes at a distant location, transforming cAMP into adenosine prohormone (Hofer and Lefkimmiatis, 2007).

\section{Role of cAMP in cancer}

The regulatory roles of cGMP and cAMP involve various types of cells and tissues and, in particular, cancer growth (McKnight, 1991). Downstream effectors, such as PKA, interact with and cause different kinds of cancer (Caretta and Mucignat-Caretta, 2011). The signaling mechanism and branch process (McKnight, 1991) are covered by cAMP. The cGMP and 
Table 2. cAMP detection methods.

\begin{tabular}{|c|c|c|c|}
\hline $\begin{array}{l}\text { Sr. } \\
\text { No. }\end{array}$ & Methods & Uses & Working \\
\hline 1 & Radioimmunoassay (RIA) & $\begin{array}{l}\text { A RIA (Wedegaertner et al., 1995) } \\
\text { was developed in the 1970s to detect cAMP } \\
\text { concentration. }\end{array}$ & $\begin{array}{l}\text { An RIA is a method with a competitive inhibition response, high } \\
\text { sensitivity, strong characteristics, and low costs (Chen et al., 1999). }\end{array}$ \\
\hline 2 & $\begin{array}{l}\text { Enzyme-linked } \\
\text { immunosorbent assay }\end{array}$ & $\begin{array}{c}\text { The enzyme-linked immunosorbent assay } \\
\text { subsequently developed provides more advantages } \\
\text { than an RIA. }\end{array}$ & $\begin{array}{l}\text { The cAMP levels are based on polyclonal anti-cAMP antibodies } \\
\text { purified in non-affinity (Moon et al., 2011). }\end{array}$ \\
\hline 3 & LANCE $^{\circledR}$-cAMP assay & $\begin{array}{c}\text { The LANCE }{ }^{\circledR}-\mathrm{cAMP} \text { Life and Theoretical } \\
\text { Sciences, Inc. An alternative approach for cAMP } \\
\text { stage assessment (Shelton, CT) }\end{array}$ & $\begin{array}{l}\text { Cellular therapy is conducted after the dilution of the samples, and } \\
\text { the cAMP amount intra-cellular is assessed using the LANCE }{ }^{\circledR} \text { - } \\
\text { cAMP kit (Avni et al., 2010). }\end{array}$ \\
\hline 4 & cAMP assay & $\begin{array}{l}\text { cAMP enzyme immunoassay kit is used to detect } \\
\text { cAMP }\end{array}$ & $\begin{array}{l}\text { Cells were seeded and medical items treated. Following opioid } \\
\text { therapy, filters were conveniently excised from the plastic supports } \\
\text { and immersed in } 0.1 \mathrm{M} \mathrm{HCl} \text { and incubated for } 15 \text { minutes at room } \\
\text { temperature. The samples were then centrifuged at room temperature } \\
\text { for } 5 \text { minutes at } 600 \mathrm{~g} \text {. }\end{array}$ \\
\hline 5 & $\begin{array}{l}\text { The homogeneous time- } \\
\text { resolved fluorescence } \\
\text { technology }\end{array}$ & $\begin{array}{l}\text { Uses anti-cAMP antibodies labeled with europium } \\
\text { and cAMP labeled with alphycocyanine modified. }\end{array}$ & $\begin{array}{l}\text { Such two fluorescent molecules are right at hand without the cellular } \\
\text { cAMP, Fürster resonance energy transfer (FRET), and long-term } \\
\text { fluorescence at two separate wavelengths. Since all molecules are } \\
\text { isolated by cellular cAMP rivalry, there is no FRET to identify the } \\
\text { only Europium emission (Williams, 2004). }\end{array}$ \\
\hline
\end{tabular}

cAMP regulatory roles primarily cover various types of cells and tissues and cancer development. The presence and activation of downstream effectors, including PKA (Caretta and MucignatCaretta, 2011), were associated with different cancer types. Cellspecific cancers recognize the distinct roles of cGMP and cAMP in cell life or death. In identified epithelial tumors with active PKA and downstream [e.g., exchange protein directly activated by cAMP (EPAC) and CREB] effectors, oncogenic cAMP activity is present (Fajardo et al., 2014).

A wide variety of hormones, neurotransmitters, and other receptor molecules use cAMP as intracellular mediators. As a growth and deterioration factor for cAMP, cAMP can directly regulate a wide range of extracellular and intracellular signals. The activation of AC enzymes combined with G proteins, such as nicotinic acetyl column receptors, beta-adrenergic receptors, or adenosine receptors, is recorded by several heterotrimeric receptors contributing to the development of cAMP (Sapio et al., 2017). The development of prostate carcinoma cell tumors reduced RII beta production, and increased R.I. alpha promotes tumor growth in these tumors. Nucleotides are the basis for various biochemical intracellular processes involving oxygen, pentosis, and one or more communities of phosphates. It is used as a substrate for energy (ATP and GTP), coenzymes (flavin adenine the nucleotides, nicotinamide dinucleotides, and coenzymes A), deoxyribonucleic acid (DNA), ribonucleic acid (RNA), and physiological regulators (Errante et al., 2017). These phosphorylate-target proteins contribute to apoptosis, cell growth suspension, and motility blockage (Li et al., 2006). Cell-specific cancers identify different cGMP and cAMP roles during cell life or death. cAMP oncogenic activity occurs with active PKA and downstream effectors (e.g., EPAC and CREB) (Fajardo et al., 2014). A wide variety of hormones, neurotransmitters, and other receptor molecules use cAMP as intracellular mediators. As a growth and deterioration factor for cAMP, cAMP can directly regulate a wide range of extracellular and intracellular signals. The activation of AC enzymes combined with G proteins, such as nicotinic acetyl column receptors, beta-adrenergic receptors, or adenosine receptors, is recorded by several heterotrimeric receptors contributing to the development of cAMP (Sapio et al., 2017). Prostate carcinoma cell tumor formation reduces RII beta production, and increased R.I. alpha encourages tumor growth in these tumors. For oxygen, pentosis, and one or more phosphate communities, nucleotides form the basis of distinct intracellular biochemical pathways. It is used as a substrate for energy (ATP and GTP), coenzymes (flavin adenine the nucleotides, nicotinamide dinucleotides, and coenzymes A), DNA, RNA, and physiological regulators (Errante et al., 2017). These phosphorylates lead to apoptosis, cell growth arrest, and motility blocking (Li et al., 2006) (Fig. 10).

\section{Drug-cAMP interaction examples}

Salmeterol (increases cAMP): This is frequently used to treat asthma and chronic obstructive pulmonary disease, but little is known about its cellular pharmacological effects. This analysis provides insights into the cellular and molecular pharmacological properties of salmeterol.

A multi-step mechanism activating phosphorylation by PK-A and G-coupled receptor kinases in the cytoplasmic tail of the third intracellular loop of the receptor is $\beta 2$ adrenergic receptor agonistic desensitization. PKA-mediated receptor and receptor phosphorylation is called "heterologous" increasing in cAMP response (Moore et al., 2007).

Theophylline (increases cAMP): For the treatment of obstructive airway disorders, theophylline is used. In addition, the discovery and role of particular PDE isoenzymes as potential antiasthma drugs have led to multiple isoenzyme-selective inhibitors.

Theophylline, known as an inhibitor of the cyclic nucleotide PDE enzyme activity, has been shown to achieve 


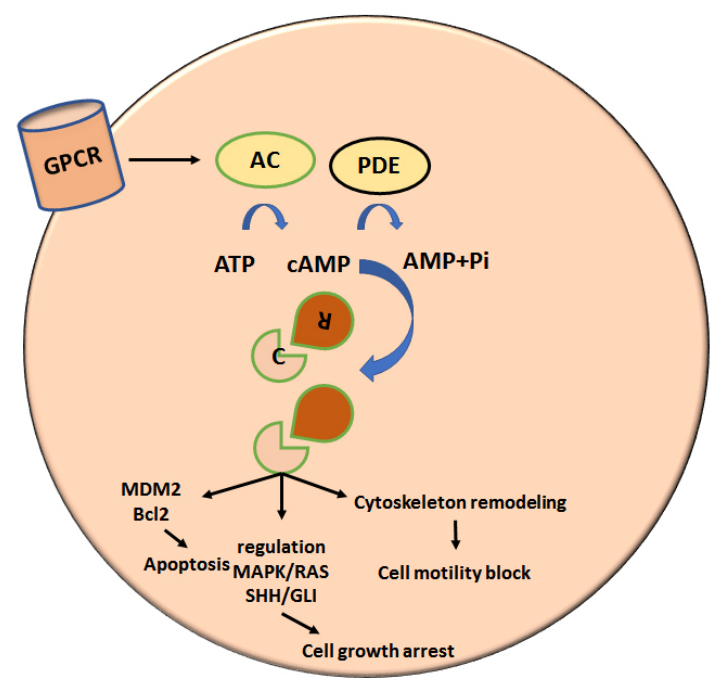

Figure 10. Involvement of the $\mathrm{CAMP} / \mathrm{PKA}$ regulatory in cancers. AC: Adenylyl cyclase; ATP: Adenosine triphosphate; cAMP: Adenosine 3',5' cyclic monophosphate; Bcl-2: B-cell lymphoma 2; GLI: Gliomaassociated oncogene homolog; GPCR: G-protein-coupled receptor; MAPK: Mitogen-activated protein kinase; MDM2: Mouse double minute 2; PDE: Phosphodiesterase; RAS: Renin-angiotensin system; SHH: Sonic hedgehog.

many of its important therapeutic effects by PDE inhibition. Such activation increases the concentration of cAMP (Moore et al., 2007).

Metoprolol (decreases cAMP): Metoprolol is widely used for the treatment of angina, hypertension, heart failure, etc. The weakening human heart is stimulated adrenergically, which increases contractility and heart rate and helps preserve short-term cardiac output.

$\beta$-adrenergic receptors are coupled to the effector enzyme AC through the "stimulatory" G protein, transforming MgATP to base. A positively inotropic and chronotropic second carrier, cAMP, is highly growth-promoting. Metoprolol medication targeting cAMP signaling lowers cAMP levels (Bristow, 2000).

Desmopressin (increases cAMP): Vasopressin stimulates the production of multiple loci renal PGE2 and modulates PGE2 antidiuresis. Elevated urinary PGE2 periods close to antidiuretic responses to arginine vasopressin and dDAVP (Desmopressin) were observed in patients with central diabetes insipidus.

In antidiuresis, $\mathrm{AC}$ is stimulated by vasopressin occupancy of $\mathrm{V} 2$ receptors in renal collecting ducts, resulting in increased intracellular cAMP levels, activating PKA (Glorian and Limon, 2013; Moses et al., 1985).

Morphine (decreases cAMP): Key medical use of morphine for chronic pain requires peripheral utilization of opioid receptor agonists. Chronic administration of morphine resulted in diminished phosphorylation by PKA of $\mu$-receptors. Since PKA activity has been shown to increase in the brain of morphinetolerant mice, this decrease in phosphorylation of the $\mu$-receptor suggests that the morphine-tolerant state will structurally or conformationally alter the $\mu$-receptor (Bernstein and Welch, 1998).
Ranitidine: Histamine2-receptor blocker drug (Ranitidine) is commonly used in clinical pharmacology to diagnose and prevent acid-peptic disorders, such as peptic ulcers, and gastroesophageal reflux disorder.

A typical $\mathrm{H} 1$ antihistamine, such as diphenhydramine, does not inhibit the H2-type histamine receptor on the basolateral membrane of the acid-secreting parietal cell. AC, the intracellular cAMP concentration, is induced by histamine-released $\mathrm{H} 2$ receptor occupation by mast cells and other potential cells (Feldman and Burton, 1990).

\section{Recent developments in the second messenger}

\section{Ceramide: a novel second messenger}

Sphingomyelin has been identified as a structural portion of the outer leaflet of the mammalian cell plasma membrane. However, it has become evident in the last 5 years that sphingomyelin is increasingly degraded and resynthesized in a signal transduction cycle that can work. Indeed, at least one DAG (Diacyl glycerol) cytokine, the tumor necrosis factor, is now known to play on this pathway in signal transduction. In addition, some cell surface receptors can also use this mechanism for signaling (Kolesnick, 1992; Liang, 2017b). Today, with the advent of increasingly advanced research techniques, the complexity involved in maintaining and measuring $3 \mathrm{D}$, temporal cAMP gradients in cell models can be glimpsed (Lu et al., 2001).

\section{Expected significance of clinical trial and artificial intelligence (AI) for the second messenger}

To treat an obsessive-compulsive disorder, a newly developed drug called DSP-1181 is used as a long-acting and powerful 5-HT1A (serotonin) receptor agonist using AI technology. And Oxford-based Exscientia is about to hit the human clinical trial first. Such a type of k marker may be used for second messengers, such as the AI system, to treat and prevent many diseases. However, when science progresses to next-level scientific knowledge, genomics, body regulators, and specialized clinical work are required. For example, for enhanced communication, AI can be used to perceive medical effects, diagnose disease, and send artificial signals to internal tissues outside the body. More work and execution, using these principles, will prepare AI for second messengers.

\section{Patents related to second messengers}

Patents relating to recent innovations, second messenger detection methods, and drugs used as cAMP to date are listed in Table 3.

\section{Future aspect}

To clarify the cAMP signaling mechanism, test protocols will be improved. The recently created high-performance and high-content screening methods can be used to promote scanning for inhibitors and agonists of the cAMP signaling system and increase innovative product imaginative scientists' abilities. Given the current situation of cAMP in plants, it seems more appropriate to exploit the expertise of some laboratories, e.g., chromatin immunoprecipitation has been shown to shorten the early drug 
Table 3. Patents on recent inventions with a detailed summary.

\begin{tabular}{|c|c|c|c|c|}
\hline Sr. No. & Name of inventor & Title and summary & Patent no. & Year \\
\hline 1 & Binkowski Brock et al. & $\begin{array}{c}\text { cAMP luciferase biosensors. This patent presented a modified luciferase } \\
\text { protein that acts as a sensor for a molecule containing cAMP. Protein contains } \\
\text { one or more heterologous amino acid sequences. At least one was specifically } \\
\text { and indirectly interacting with cAMP, which shows an answer that regulates } \\
\text { the interaction between the modified luciferase cAMP binding site and } \\
\text { molecule (Schmidt et al., 1999). }\end{array}$ & JP2015091253A & 2018 \\
\hline 2 & Arnd Baumann et al. & $\begin{array}{l}\text { Systems for the identification of second messengers comprising fluorescence } \\
\text { sensor proteins and a cycle tool. The second messenger was controlled using } \\
\text { a fluorescence-containing sensor protein (FCSP). FCSP defined it applied to } \\
\text { the container and calculation of fundamental fluorescence without the second } \\
\text { messenger and the second messenger is then attached to the container and } \\
\text { inflorescence is determined by shift (Wiesweg, 2014) }\end{array}$ & WO2018188679A1 & 2018 \\
\hline 4 & Robert I. Henkin & $\begin{array}{c}\text { Treatment inhibiting PDE. This patent provided a system and composition } \\
\text { used to treat disease or disorders created or correlated with low cyclic } \\
\text { nucleotide rates. PDE hydrolyzes cyclic nucleotides that modulate } \\
\text { intracellular levels of the second messengers cAMP and cGMP (Rodragguez- } \\
\text { Iturbe et al., 2005). }\end{array}$ & US20100022563A1 & 2010 \\
\hline 3 & Kees Jalink & $\begin{array}{l}\text { Biosensor detecting camp levels and use methods. This patent supported an } \\
\text { Epacl or Epac2 polypeptide biosensor to detect cAMP concentration. The first } \\
\text { region, tripartite fusion polypeptide and Epac polypeptide contained cAMP } \\
\text { binding site; the second region, first fluorescent polypeptide domain; the third } \\
\text { region, second fluorescent polypeptide domain (Mukherjee et al., 2016). }\end{array}$ & WO2006054167A2 & 2006 \\
\hline \multirow[t]{2}{*}{5} & $\begin{array}{l}\text { Viacheslav Nikolaev } \\
\text { Moritz Bünemann }\end{array}$ & $\begin{array}{l}\text { Means and strategies for in-vitro community commitment. There were } \\
\text { chimeric peptides in this patent compressing the cAMP binding moiety. } \\
\text { However, there is only one binding site, with at least two detectable labels } \\
\text { (Goutier et al., 2010). }\end{array}$ & EP1687441B1 & 2006 \\
\hline & Martin J. Lohse & & & \\
\hline 6 & $\begin{array}{l}\text { Jochen Buck } \\
\text { Lonny R. Levin }\end{array}$ & $\begin{array}{l}\text { Mammalian AC. This patent gave isolated animal soluble AC and modulated } \\
\text { its expression and activity. It also provided methods to use soluble AC to treat } \\
\text { pathological conditions and track blood gases (Buck and Levin, 2003). }\end{array}$ & EP1282633A1 & 2000 \\
\hline 7 & $\begin{array}{c}\text { Roger Y. Tsien, } \\
\text { Wenhong Li }\end{array}$ & $\begin{array}{l}\text { They caged membrane-permeant phosphates. In this patent, caged inositol } \\
\text { phosphate-containing acyloxyalkyl esters, which permeated the cell } \\
\text { membrane and contained the second 6-hydroxyl (photolabile group). The } \\
\text { ester derivative then undergoes enzymatic conversion to remove the cell's } \\
\text { acyloxyalkyl ester groups. The compound was biologically inactive under } \\
\text { ultraviolet light. Upon ultraviolet light penetration, the second messenger's } \\
\text { active mode is released into the cell (Tsien and Li, 1999). }\end{array}$ & US5866548A & 1996 \\
\hline
\end{tabular}

cycle considerably, and recent developments in flow cytometry have resulted in 30 times faster sequential sample processing.

\section{CONCLUSION}

Cell receptors obtain information immediately, efficiently, and effectively as a second messenger, causing physiological changes at the cell level such as growth, differentiation, invasion, replication, apoptosis, and depolarization. The study established the function of cAMP as the second messenger. Furthermore, it fathomed the signal transduction process that causes cells to respond to environmental signals by amplifying this signal. Many second messengers have reduced the lower ion channel's receptor and neurotransmitter activities, but cAMP has more than most. Similar functions and second messenger patent research indicate unique biosensors and cAMP detection methods useful in various therapies and disease prevention. So, since it controls different protein and enzyme functions, it is easy to recognize and infer as a crucial second messenger. Using various parameters, such as patient data analysis and disease diagnosis, the current AI system is important in medicine. These parameters can also be used in the future for second messengers to diagnose and prevent certain diseases.

\section{LIST OF ABBREVIATIONS}

AC: Adenylyl cyclase; ATF-1: Activating transcription factor-1; ATP: Adenosine triphosphate; cAMP: Adenosine 3',5' cyclic monophosphate; cGMP: Guanosine 3',5' cyclic monophosphate; CO: Carbon monoxide; CREB: cAMP response element binding protein; DAG: Diacylglycerol; ER: Endoplasmic reticulum; GDP: Guanosine diphosphate; GPCR: G-proteincoupled receptor; GTP: Guanosine triphosphate; ICER: Inducible cAMP early repressor; IP3: inositol-1,4,5-triphosphate; NO: Nitric oxide; PDE: Phosphodiesterase; PGE: Prostaglandins; PIP2: Phosphatidylinositol 4, 5-bisphosphate; PK: Protein kinase; PLC: Phospholipase C; RTK: Receptor tyrosine kinase; sGC: Soluble guanylyl cyclases; SHH: Sonic hedgehog. 


\section{AUTHOR CONTRIBUTIONS}

All authors made substantial contributions to conception and design, acquisition of data, or analysis and interpretation of data; took part in drafting the article or revising it critically for important intellectual content; agreed to submit to the current journal; gave final approval of the version to be published; and agree to be accountable for all aspects of the work. All the authors are eligible to be an author as per the international committee of medical journal editors (ICMJE) requirements/guidelines.

\section{CONFLICT OF INTEREST}

All authors declare that there is no conflict of interest.

\section{FUNDING}

There is no funding to report.

\section{CONFLICTS OF INTEREST}

The authors report no financial or any other conflicts of interest in this work.

\section{ETHICAL APPROVALS}

This study does not involve experiments on animals or human subjects.

\section{DATA AVAILABILITY}

All data generated and analyzed are included within this research article.

\section{PUBLISHER'S NOTE}

This journal remains neutral with regard to jurisdictional claims in published institutional affiliation.

\section{REFERENCES}

$\mathrm{Ab}$ Naafs M. Second messengers in endocrinology: a mini-review of the cyclic nucleotides. Endocrinol Metab Int J, 2017; 5(6): 347-50.

Alberts B, Bray D, Johnson A, Lewis J, Raff M, Roberts K, Walter P. Essential cell biolog. W.W. Norton \& Company, New York, NY, 2013.

Assmann SM. Cyclic AMP as a second messenger in higher plants (status and future prospects). Plant Physiol, 1995; 108(3):885.

Avni D, Ernst O, Philosoph A, Zor T. Role of CREB in modulation of TNF $\alpha$ and IL-10 expression in LPS-stimulated RAW264. 7 macrophages. Mol Immunol, 2010; 47(7-8):1396-403.

Baillie GS. Compartmentalized signalling: spatial regulation of cAMP by the action of compartmentalized phosphodiesterases. FEBS J, 2009; 276(7):1790-9.

Barrett KE, Boitano S, Barman SM, Brooks HL. Ganong's review of medical physiology twenty. McGraw-Hill Education - Maidenhead SL6 3UD, United Kingdom. 2010.

Beavo JA, Brunton LL. Cyclic nucleotide research -- still expanding after half a century. Nat Rev Mol Cell Biol, 2002; 3(9):710-8.

Bernstein MA, Welch SP. mu-Opioid receptor down-regulation and cAMP-dependent protein kinase phosphorylation in a mouse model of chronic morphine tolerance. Brain Res Mol Brain Res, 1998; 55(2):237-42.

Berridge MJ, Bootman MD, Roderick HL. Calcium signalling: dynamics, homeostasis and remodelling. Nat Rev Mol Cell Biol, 2003; 4(7):517-29.

Brady S. Basic neurochemistry: molecular, cellular and medical aspects. Elsevier, Amsterdam, Netherlands, 2005.

Bristow MR. beta-adrenergic receptor blockade in chronic heart failure. Circulation, 2000; 101(5):558-69.

Broillet MC, Firestein S. Gaseous second messengers in vertebrate olfaction. J Neurobiol, 1996; 30(1):49-57.
Brudvik KW, Paulsen JE, Aandahl EM, Roald B, Tasken K. Protein kinase A antagonist inhibits beta-catenin nuclear translocation, c-Myc and COX-2 expression and tumor promotion in Apc (Min/+) mice. Mol Cancer, 2011; 10(1):149. Google Patents.

Buck J, Levin LR, 2003. Mammalian soluble adenylyl cyclase.

Butcher RW, Robison GA, Hardman JG, Sutherland EW. The role of cyclic AMP in hormone actions. Adv Enzyme Regul, 1968; 6:357-89.

Caretta A, Mucignat-Caretta C. Protein kinase a in cancer Cancers (Basel), 2011; 3(1):913-26.

Chen CC, Chiu KT, Sun YT, Chen WC. Role of the cyclic AMP-protein kinase A pathway in lipopolysaccharide-induced nitric oxide synthase expression in RAW 264.7 macrophages. Involvement of cyclooxygenase-2. J Biol Chem, 1999; 274(44):31559-64.

Clapham DE. Calcium signaling. Cell, 1995; 80(2):259-68.

Clarke JI, Brillanf N, Antoine DJ. Novel circulating- and imaging-based biomarkers to enhance the mechanistic understanding of human drug-induced liver injury. J Clin Transl Res, 2017; 3(1):199-211.

Colon-Gonzalez F, Kazanietz MG. C1 domains exposed: from diacylglycerol binding to protein-protein interactions. Biochim Biophys Acta, 2006; 1761(8):827-37.

Cooper DM. Bimodal regulation of adenylate cyclase. FEBS Lett, 1982; 138(2):157-63.

Danchin A. Phylogeny of adenylyl cyclases. Adv Second Messenger Phosphoprotein Res, 1993; 27:109-62.

Das DK. Redox regulation of ischemic heart disease, pathophysiology of cardiovascular disease. Springer, New York, NY, pp 203-21. 2004.

de Wit RJ, Hoppe J, Stec WJ, Baraniak J, Jastorff B. Interaction of cAMP derivatives with the 'stable'cAMP-binding site in the cAMPdependent protein kinase type I. Eur J Biochem, 1982; 122(1):95-9.

Dennis EA, Rhee SG, Billah MM, Hannun YA. Role of phospholipase in generating lipid second messengers in signal transduction. FASEB J, 1991; 5(7):2068-77.

Dousa TP, Dozois RR. Interrelationships between histamine, prostaglandins, and cyclic AMP in gastric secretion: a hypothesis. Gastroenterology, 1977; 73(4):904-12.

Errante P, Menezes-Rodrigues F, Leite A, Caricati-Neto A, Bergantin L. New antitumoral pharmacological strategies involving $\mathrm{Ca} 2+$ cAMP signaling pathways. J Cancer Epidem Prev, 2017; 2:1-6.

Fajardo AM, Piazza GA, Tinsley HN. The role of cyclic nucleotide signaling pathways in cancer: targets for prevention and treatment. Cancers (Basel), 2014; 6(1):436-58.

Feldman M, Burton ME. Histamine2-receptor antagonists: standard therapy for acid-peptic diseases. N Engl J Med, 1990; 323(24):1672-80

Fimia GM, Sassone-Corsi P. Cyclic AMP signalling. J Cell Sci, 2001; 114(Pt 11):1971-2.

Friebe A, Sandner P, Schmidtko A. cGMP: a unique 2nd messenger molecule - recent developments in cGMP research and development. Naunyn Schmiedebergs Arch Pharmacol, 2020; 393(2):287302 .

Gerfen CR, Bolam JP. The neuroanatomical organization of the basal ganglia, handbook of behavioral neuroscience. Elsevier, Amsterdam, Netherlands, pp 3-28, 2010

Glorian M, Limon I. The role of cyclic 3'-5'adenosine monophosphate (camp) in differentiated and trans-differentiated vascular smooth muscle cells. IntechOpen Limited, London, SW7 2QJ, UNITED KINGDOM. 2013.

Gold MG, Gonen T, Scott JD. Local cAMP signaling in disease at a glance. J Cell Sci, 2013; 126(Pt 20):4537-43.

González-Espinosa C, Guzmán-Mejía F. Basic elements of signal transduction pathways involved in chemical neurotransmission, identification of neural markers accompanying memory. Elsevier, Amsterdam, Netherlands, pp 121-33, 2014.

Goutier W, Spaans P, Van der Neut M, McCreary A, Reinders J. Development and application of an LC-MS/MS method for measuring 
the effect of (partial) agonists on cAMP accumulation in vitro. J Neurosci Methods, 2010; 188(1):24-31.

Graham RM, Perez DM, Hwa J, Piascik MT. alpha 1-adrenergic receptor subtypes. Molecular structure, function, and signaling. Circ Res, 1996; 78(5):737-49.

Greene SJ, Gheorghiade M, Borlaug BA, Pieske B, Vaduganathan M, Burnett JC, Jr., Roessig L, Stasch JP, Solomon SD, Paulus WJ, Butler $\mathrm{J}$. The cGMP signaling pathway as a therapeutic target in heart failure with preserved ejection fraction. J Am Heart Assoc, 2013; 2(6):e000536.

Hanaoka K, Guggino WB. cAMP regulates cell proliferation and cyst formation in autosomal polycystic kidney disease cells. J Am Soc Nephrol, 2000; 11(7):1179-87.

Hoeffler JP, Meyer TE, Yun Y, Jameson JL, Habener JF. Cyclic AMP-responsive DNA-binding protein: structure based on a cloned placental cDNA. Science, 1988; 242(4884):1430-3.

Hofer AM, Lefkimmiatis K. Extracellular calcium and cAMP second messengers as "third messengers"? Physiology, 2007; 22(5):320-7.

Hongjun L. Risk assessment and countermeasures of fall in elderly patients. J Clin Nurs Res, 2017;1(1):7-8.

Houslay M. Tailoring cAMP-signalling responses through isoform multiplicity. Trends Biochem Sci, 1997; 22(6):217-24.

Huang WC, Xie Z, Konaka H, Sodek J, Zhau HE, Chung LW. Human osteocalcin and bone sialoprotein mediating osteomimicry of prostate cancer cells: role of cAMP-dependent protein kinase A signaling pathway. Cancer Res, 2005; 65(6):2303-13.

Hughes AR, Putney JW, Jr. Inositol phosphate formation and its relationship to calcium signaling. Environ Health Perspect, 1990; 84:141-7.

Jing L, Sun J, Liu H, Wang X, Huang D. Using plant proteins to develop composite scaffolds for cell culture applications. Int J Bioprint, 2021; 7(1):298.

Katzung BG, Katzung BG. The Eicosanoids: Prostaglandins, Thromboxanes, Leukotrienes, \& Related Compounds. In: Basic \& clinical pharmacology. 14th edition. Editor: Betram G. Katzung, (ed.). McGrawHill, New York, NY, 2018.

Kolesnick R. Ceramide: a novel second messenger. Trends Cell Biol, 1992; 2(8):232-6.

Kong L. Clinicopathological features of simple primary squamous cell carcinoma of breast. Proc Anticancer Res, 2017;1(1):6-8.

Kukreja RC. Phosphodiesterase-5 and retargeting of subcellular cGMP signaling during pathological hypertrophy. Circulation, 2012; 126(8):916-9.

Kukreja RC, Salloum FN, Das A. Cyclic guanosine monophosphate signaling and phosphodiesterase-5 inhibitors in cardioprotection. J Am Coll Cardiol, 2012; 59(22):1921-7.

Lee D. Global and local missions of cAMP signaling in neural plasticity, learning, and memory. Front Pharmacol, 2015; 6:161.

Lee HJ, Koo YW, Yeo M, Kim SH, Kim GH. Recent cell printing systems for tissue engineering. Int J Bioprint, 2017; 3(1):004

Leinders-Zufall T, Shepherd GM, Zufall F. Regulation of cyclic nucleotide-gated channels and membrane excitability in olfactory receptor cells by carbon monoxide. J Neurophysiol, 1995; 74(4):1498-508.

Li Y, Shaw S, Kamsteeg EJ, Vandewalle A, Deen PM Development of lithium-induced nephrogenic diabetes insipidus is dissociated from adenylyl cyclase activity. J Am Soc Nephrol, 2006; 17(4):1063-72.

Li Z, Li F, Tang H, Ge X, Xu L, Yu C. Identification of driver genes in lung squamous cell carcinoma and lung adenocarcinoma. Cancer, 2020;1(4):23-8.

Liang TJ. Drug resistance mechanism of Staphylococcus aureus bacterial biofilm. J Clin Nurs Res, 2017a; 1(1): 20-5.

Liang X. Risk factors and strategies of anastomotic fistula after sphincter-pre-serving surgery for laparoscopic rectal cancer. Proc Anticancer Res, 2017b; 1(1):6-8.

Limbird LE. Cell surface receptors: a short course on theory and methods: a short course on theory and methods. Springer Science \& Business Media, Berlin/Heidelberg, Germany. 2012.

Lincoln TM, Cornwell TL. Intracellular cyclic GMP receptor proteins. FASEB J, 1993; 7(2):328-38.
Liscovitch M, Cantley LC. Lipid second messengers. Cell, 1994, 77(3):329-34

Loomans J, Stokhuijzen E, Peters M, Fijnvandraat K. Administration of DDAVP did not improve the pharmacokinetics of FVIII concentrate in a clinically significant manner. J Clin Transl Res, 2018; $3: 351-7$.

Lu Y, Parkyn L, Otterbein LE, Kureishi Y, Walsh K, Ray A, Ray P. Activated Akt protects the lung from oxidant-induced injury and delays death of mice. J Exp Med, 2001; 193(4):545-9.

Martínez M, Fernández E, Frank A, Guaza C, de la Fuente M, Hernanz A. Increased cerebrospinal fluid cAMP levels in Alzheimer's disease. Brain Res, 1999; 846(2):265-7.

Maurice DH, Palmer D, Tilley DG, Dunkerley HA, Netherton SJ, Raymond DR, Elbatarny HS, Jimmo SL. Cyclic nucleotide phosphodiesterase activity, expression, and targeting in cells of the cardiovascular system. Mol Pharmacol, 2003; 64(3):533-46.

McKnight GS. Cyclic AMP second messenger systems. Curr Opin Cell Biol, 1991; 3(2):213-7.

McLean JH, Smith A, Rogers S, Clarke K, Darby-King A, Harley CW. A phosphodiesterase inhibitor, cilomilast, enhances cAMP activity to restore conditioned odor preference memory after serotonergic depletion in the neonate rat. Neurobiol Learn Mem, 2009; 92(1):63-9.

Meyer JS. Principles of neurotransmission and implications for network modeling, neural-network models of cognition - biobehavioral foundations. Elsevier, Amsterdam, Netherlands, pp 82-104, 1997.

Moon EY, Lee JH, Lee JW, Song JH, Pyo S. ROS/Epac1-mediated Rap1/NF-kappaB activation is required for the expression of BAFF in Raw264. 7 murine macrophages. Cell Signal, 2011; 23(9):1479-88.

Moore RH, Millman EE, Godines V, Hanania NA, Tran TM, Peng H, Dickey BF, Knoll BJ, Clark RB. Salmeterol stimulation dissociates $\beta 2$-adrenergic receptor phosphorylation and internalization. Am J Resp Cell Mol Biol, 2007; 36(2):254-61.

Moses AM, Scheinman SJ, Schroeder ET. Antidiuretic and PGE2 responses to AVP and dDAVP in subjects with central and nephrogenic diabetes insipidus. Am J Physiol, 1985; 248(3 Pt 2):F354-9.

Mukherjee S, Jansen V, Jikeli JF, Hamzeh H, Alvarez L, Dombrowski M, Balbach M, Strunker T, Seifert R, Kaupp UB, Wachten D. A novel biosensor to study cAMP dynamics in cilia and flagella. Elife, 2016; 5:e14052.

Newton AC, Bootman MD, Scott JD. Second messengers. Cold Spring Harb Perspect Biol, 2016; 8(8):a005926.

Parys JB, De Smedt H. Inositol 1,4,5-trisphosphate and its receptors, advances in experimental medicine and biology. Springer Netherlands, Dordrecht, Netherlands, pp 255-79, 2012.

Prasad KN. Role of cyclic AMP in developing brain, biochemistry of brain. Elsevier, Amsterdam, Netherlands, pp 479-522, 1980.

Prokazova NV, Samovilova NN, Golovanova NK, Gracheva EV, Korotaeva AA, Andreeva ER. Lipid second messengers and cell signaling in vascular wall. Biochemistry (Mosc), 2007; 72(8):797—808.

Raker VK, Becker C, Steinbrink K. The cAMP pathway as therapeutic target in autoimmune and inflammatory diseases. Front Immunol, 2016a; 7:123.

Raker VK, Becker C, Steinbrink K. The cAMP pathway as therapeutic target in autoimmune and inflammatory diseases. Front Immunol, 2016b; 7:123.

Ravnskjaer K, Madiraju A, Montminy M. Role of the cAMP pathway in glucose and lipid metabolism. Metabolic Control, 2015:29-49.

Reymond CD, Schaap P, Veron M, Williams JG. Dual role of cAMP during dictyostelium development. Experientia, 1995; 51(12):1166-74.

Rhee SG. Regulation of phosphoinositide-specific phospholipase C. Annu Rev Biochem, 2001; 70(1):281-312.

Rodragguez-Iturbe B, Ferrebuz A, Vanegas V, Quiroz Y, Espinoza F, Pons H, Vaziri ND. Early treatment with cGMP phosphodiesterase inhibitor ameliorates progression of renal damage. Kidney Int, 2005; 68(5):2131-42

Sapio L, Gallo M, Illiano M, Chiosi E, Naviglio D, Spina A, Naviglio S. The natural cAMP elevating compound forskolin in cancer therapy: is it time? J Cell Physiol, 2017; 232(5):922-7. 
Schmidt D, Dent G, Rabe KF. Selective phosphodiesterase inhibitors for the treatment of bronchial asthma and chronic obstructive pulmonary disease. Clin Exp Allergy, 1999; 29(Suppl 2):99-109.

SIA S. Role of hormonal manipulation in prostate cancer management. Proc Anticancer Res, 2018; 2(1):45-53.

Spina A, Di Maiolo F, Esposito A, D'Auria R, Di Gesto D, Chiosi E, Sorvillo L, Naviglio S. Integrating leptin and cAMP signalling pathways in triple-negative breast cancer cells. Front Biosci (Landmark Ed), 2013; 18:133-44.

Sprenger JU, Perera RK, Steinbrecher JH, Lehnart SE, Maier LS, Hasenfuss G, Nikolaev VO. In vivo model with targeted cAMP biosensor reveals changes in receptor-microdomain communication in cardiac disease. Nat Commun, 2015; 6(1):1-11.

Strewler GJ. Release of cAMP from a renal epithelial cell line. Am J Physiol, 1984; 246(3 Pt 1):C224-30.

Strømland Ø, Kakubec M, Halskau Ø. Detection of mis-folded protein aggregates from a clinical perspective. J Clin Transl Res, 2016; 2(1):11-26.

Sutherland EW, Rall TW. The properties of an adenine ribonucleotide produced with cellular particles, ATP, $\mathrm{Mg}++$, and epinephrine or glucagon. J Am Chem Soc, 2002; 79(13):3608.

Sutherland EW, Robison GA. The role of cyclic AMP in the control of carbohydrate metabolism. Diabetes, 1969; 18(12):797-819.

Takagi D, Lin W, Matsumoto T, Yaginuma H, Hemmi N, Hatada S, Seo M. High-precision three-dimensional inkjet technology for live cell bioprinting. Int J Bioprint, 2019; 5(2):208.

Thatcher JD. The inositol trisphosphate (IP3) signal transduction pathway. Sci Signal, 2010; 3(119):tr3.

Tsai EJ, Kass DA. Cyclic GMP signaling in cardiovascular pathophysiology and therapeutics. Pharmacol Ther, 2009; 122(3):216-38.

Tsien RY, Li W, 1999. Caged membrane-permeant inositol phosphates. Google Patents.

Tsui MM, York JD. Roles of inositol phosphates and inositol pyrophosphates in development, cell signaling and nuclear processes. Adv Enzyme Regul, 2010; 50(1):324-37.

Vang T, Torgersen KM, Sundvold V, Saxena M, Levy FO, Skalhegg BS, Hansson V, Mustelin T, Tasken K. Activation of the COOHterminal Src kinase (Csk) by cAMP-dependent protein kinase inhibits signaling through the T cell receptor. J Exp Med, 2001; 193(4):497-507.

Verma A, Hirsch DJ, Glatt CE, Ronnett GV, Snyder SH. Carbon monoxide: a putative neural messenger. Science, 1993; 259(5093):381-4.
Wedegaertner PB, Wilson PT, Bourne HR. Lipid modifications of trimeric G proteins. J Biol Chem, 1995; 270(2):503-6.

Wehbi VL, Taskén K. Molecular mechanisms for cAMPmediated immunoregulation in $\mathrm{T}$ cells-role of anchored protein kinase a signaling units. Front Immunol, 2016; 7:222.

Wiesweg M. Ein spezifisches Nachweisverfahren für S-Nitrosothiole. Universitätsbibliothek Duisburg-Essen, North RhineWestphalia, Germany. 2014.

Williams C. cAMP detection methods in HTS: selecting the best from the rest. Nat Rev Drug Discov, 2004; 3(2):125-35.

Xu C, Huang Y, Zhao Y. Cell "starvation" treatment-optimization of packaging methods for recombinant adenovirus vectors. J Clin Nurs Res, 2020;4(1):27-31.

Xue R, Wang H, Li N, Huang Y, Zuo Y. Primary small cell neuroendocrine carcinoma of the kidney: a case report. Cancer+, 2019; $1(3): 15-18$

Yoshida Y, Imai S. Structure and function of inositol 1,4,5-trisphosphate receptor. Jpn J Pharmacol, 1997; 74(2):125-37.

Zhang X, Zhang J, Kang X, Zhu X, Yan Y, Yang Z, Li C. Sandwich type biosensor of $\varepsilon$-subunit of FoF1-ATPase for ultrasensitivedetection of Bladder cancer cell. Cancer+, 2019; 1(1):17-23.

How to cite this article:

Muthal AP, Kulkarni R, Kumar D, Bagul C, MukherjeeKandhare AA, Kandhare AD, Ambavade SD, Wagh V, Bodhankar SL. Cyclic adenosine monophosphate : Recent and future perspectives on various diseases. J Appl Pharm Sci, 2022; 12(03):001-015. 